\title{
Eugenia Rico: The Black Cat / Translated by Anna Rosen Guercio
}

You can close your eyes but you can't close your ears.

In the darkness, I keep hearing the screams. I don't know who's screaming. I squeeze my eyes tighter and realize that I'm the one who's screaming. In the darkness, there is no hate. There's a strange smell and it isn't me. In another time and another place, someone would have known why all this was happening, someone would have been able to give a name to everything that seems so inexplicable to me, but which does have an explanation. It has to. It won't be a logical explanation.

In another life, I tried to find causes and effects until I came to understand that nothing that happened to me had them. I believed that I thought with my head. I believed that I thought.

In the darkness, I don't think with my heart or with my head. I don't have any. Others will come and they'll tell my story. It'll sound different from their lips.

I've never been different than everyone else. All my life I endeavored to stay in the middle of the road, not to be too high or too low, too smart or too dumb. I didn't want to stand out in any way and, in the end, that was the thing that made me stand out, the thing my husband fell in love with. My childhood was filled with events so sad that even in darkness they're too terrible to remember. They taught me to detest humans. A terrible father who abused my mother, a stepfather who was even worse, and unspeakable sins forced me to take refuge in a love for animals. l'd bring home baby birds fallen from their nests, stray dogs, abandoned cats. That's how I met my future husband. We were both very young. He was like a stray dog. A simple boy who recited poems, he was always laughed at by the other children because he loved animals even more than I did. Our marriage was a lucky escape. When we got married, I came into an inheritance from my late mother. That money allowed us to live in a certain amount of comfort. The first luxury we allowed 
ourselves was to share our happiness with a growing colony of animals. In those days, our little Eden was home to birds, goldfish, a beautiful dog, rabbits, a monkey, and a cat.

I loved those animals and I loved my husband even more. Back then we'd laugh together from sheer joy and the world didn't seem like a dark place anymore. I loved to feel the warmth of my sweet animals' loyalty and the pleasure they brought my husband. Every time I brought a new animal home, it was like looking at the world with new eyes. It was a joy to love someone who cared so much for the weak. l'd married a good man, nothing like my father. My husband and I spent hours and hours surrounded by our non-human friends. We trusted only them and one another.

My husband's favorite was the cat. A strange cat, as beautiful as an innocent's happiness. He was so black and so clever that my husband said he finally understood how people in the Middle Ages were so convinced that black cats were witches in disguise. This cat wasn't just as shrewd as people. He was actually smarter than most people I knew.

Plutón, which is what we called the cat, followed my husband like a dog everywhere he went. At first the animal loved me too, so much that it was hard to keep him from following me through the streets, but then my husband said I couldn't feed him anymore. He should be the one to do it and the cat should only follow him. That's when I began to stray from the path of our togetherness and when my husband began to stray from me.

I still adored him, and his aloofness just made me redouble my efforts. I brought home even more animals, but he started getting bored with them. I dressed up in my best clothes and cooked complex delicacies. My husband complained about them. One time, he threw a pot full of an exquisite bouillabaisse on the floor and there wasn't anything for dinner. That was the first day I cried. I couldn't have imagined what was coming.

If I looked too nice when he got home, he'd hit me for looking like a tart. If I hadn't brushed my hair, the beating was because I wasn't trying hard enough to make myself attractive for him. I took refuge in my memories. This wasn't him. When I got in bed with that strange man with bloodshot eyes, I felt like I was cheating on my husband, the only man l'd ever loved. The man I hadn't seen for years. Alcohol was the demon behind all of it. I couldn't blame him, because if I 
blamed him that meant giving up hope he'd come back to me. I was the first victim of his rage. He abused me, but he was kind to our animals. I clung to the little bit of tenderness that I saw when he petted the dog and, most of all, when he talked to Plutón in that sweet voice that l'd warranted when I was younger. I told myself that as long as there was a shred of humanity left inside him, it could rise like bread and bring me back the man I loved.

One time he beat me so badly that I couldn't get out of bed for days. When that happened, my husband got in bed with me, cried with me, held and kissed me. He told me how much he loved me and promised that he'd change. He swore he'd never raise his hand to me again and he'd give up the bottle that had become like an evil mistress so he could come back to his real wife.

And, for a few days, he kept his word. But just a week later, he really did change. He was falling down drunk when he got home. He put his hands around my throat and tried to strangle me. I ran and then he started kicking the dog and the monkey, who escaped in terror. It seemed to me like he was trying to use us to drown the bitterness of the alcohol defeating him. That made me imagine he was still fighting. Someplace inside him, my real husband was fighting against this person who'd taken over his body. There were still signs that the goodness inside him hadn't been completely snuffed out. He still cared about Plutón. The black cat brought out all the good that was left in him. Some nights he'd slowly stroke his head and then come to bed smiling, and that night he'd be as he once was. He'd kiss me, swear his love, beg my forgiveness for all the harm he'd inflicted. Every single one of those nights, I believed him, and I believed him in the morning too, when he said he was going out to look for work. I began to realize that the small fortune we'd inherited had slipped through our fingers. The servants each took their leave once they caught a glimpse of my husband's true character, and I didn't have the money to replace them. Before long, the only one left was an old woman who took pity on me. A one-eyed matron whom my husband hated and who told me I had to leave him. She said that she'd had a husband like him once, that he'd tried to kill her. Miraculously, she escaped, but she did lose the eye. A rag covered the bloody, empty hole. Every so often she'd show it to me, swearing that God had marked her as a sign for unhappy women, to save them from men who were not their masters, but devils. I knew that my husband really was good and that he'd never kill a fly. He might hit me, but he'd never really hurt me that badly. He was just like an animal who'd lost its way and, when the time came, I was going 
to be the one who saved him. The old woman had the nerve to tell me that maybe he wouldn't kill a fly, but he would kill his wife. "Weak women irritate men like him a lot more than flies do, and goodness, senora, is only weakness to the wicked." Oh how I wanted to fire her when she said those things. But I didn't. I could never have found anyone who'd work so hard for so little pay and she was kind to me. She was the only one who listened to my troubles and who knew why I couldn't get out of bed all those mornings.

It wasn't she who made me see that the end had come, but Plutón. One night when my husband came home blind drunk and ran into him on the stairs. The cat had grown old by then and he was slow from being spoiled with so much love. All of us in the house had fled when we saw my husband's murky eyes and caught the stink of gin, which, for me, had come to be the stink of Hell. He announced his arrival with shouting and insults, which had the virtue of giving me enough time to shut myself up in the bedroom. l'd learned to fear his arrival and hearing his key in the door was all it took to make my heart stop beating and my tongue begin to stammer.

That day there was no one left to take out his rage on. Then he saw Plutón. The cat was the only member of the household who hadn't fled from his path. My husband called sweetly and the cat ran toward him. He was going blind, but still, at the last second, he sensed that something was wrong. My husband lifted him up off the ground and the darling cat jerked back in fear. That's what set him off. I'm convinced that that was the moment when the last scrap of his soul flew from his body. Suddenly, he was naked in his darkness, and his old self, who l'd believed was the real one, abandoned him. The devil possessed him completely. He pulled out a penknife from his bag. A penknife l'd given him, never dreaming of its perverse destiny. Mercilessly, he gouged the animal's eye out like coring an apple. Maybe that's why he spent the night rambling about Eve and Original Sin through his bitter sobs. He seemed so repentant that I actually held him in my arms. But not before doing everything I could to help Plutón. I took care of him as well as I knew how to take care of myself. In the days that followed, my husband behaved with great gentleness and I hoped perhaps his sacrifice had been for something. Plutón was very sick, but, thanks to my care, he got better. The eye socket was a black hole mirroring how horrible our home had become, but it seemed like the cat was no longer in pain. Even before the eye had finished healing, my husband had already gone back to drowning all his good intentions in wine. Still, I thought we'd hit rock 
bottom and couldn't possibly fall any lower. I didn't know how wrong I was. That wasn't the end, but the beginning.

Now everyone in the house hid when we heard his footsteps: the animals, the servant, and I. We only came out if it was clear that he was in a good mood. In those effusive moments, he brought me gifts and stroked my face. Devotedly, he'd kiss the bruises that he himself had left the night before. Days like that, he'd have all of us eating out of his hand. All of us except Plutón, who ran from him with the same determination with which he used to follow at his heels. Nothing irked my husband like the cat's aversion. He slapped me when I said that he himself had caused it, but that he could fix everything by giving up the demon he adored: that demon stores sell for just a few dollars.

My husband now threw himself into wickedness like it was a love affair. With resignation, with fatalism, with pleasure. While working in the garden of our house one morning, he caught poor Plutón in cold blood. He tied a noose around his neck and hung him from a tree branch. He did it with tears in his eyes, maybe because even he knew that he was choking out the last vestige of humanity he might have left. He hung the cat because it had loved him and because it had never given him any reason to treat him badly. Just like me.

That day, I finally lost hope. I wasn't even surprised when we were woken that night by cries of "fire!" The drapes around my bed were a living flame and the entire house was burning.

The one-eyed servant, my husband, and I scarcely made it out alive. The fire had ruined us, since the house was all that remained of my inheritance. I hadn't had the courage to tell my husband I was out of money, fearing that it could make his cruelty worse. I didn't want to admit it to myself, but my worst fear was that he'd abandon me. Somehow I felt bound to him by an invisible rope, as lethal as the one he'd wrapped around the poor cat's neck.

I couldn't help remembering my childhood fears and thinking that the fire had been a punishment, not for my husband's cruelty, but for my cowardice. I didn't imagine that God was punishing me because I knew I was too insignificant to merit God's attention. The day after the fire, we went to visit the ruins together. All but one of the walls had collapsed. The one still standing was a thin partition against which the head of our bed used to stand. The plaster had saved it from the fire's 
onslaught. I recalled with bitterness that painting the house had been the last whim of my husband's l'd been able to satisfy with money. A dense crowd had gathered across from that wall, like it was a movie screen. The people yelled with surprise and squealed with excitement. When we got closer, we saw that on the white surface of the wall, engraved like a bas-relief from a museum, was the image of a gigantic cat. Its outline was marvelously sharp. Around the cat's neck, there was a rope.

On seeing this apparition, my husband let out a loud scream, grabbed my arm so he wouldn't collapse, and began to shake like he was in the grips of delirium tremens. A chill went down my spine, but I was calm. I'd already realized what must have happened. I was tempted to leave my husband right there, thinking of punishment after death, but he was so wan and pale that I took pity. I reminded him that he'd hanged the cat in the garden right alongside the house. When the fire alarms had sounded, the crowd must have invaded our garden. Someone cut the rope and threw the cat into our open bedroom window, probably in an attempt to wake us. When the walls collapsed, my husband's innocent victim got pressed against the fresh plaster, whose lime, along with the flames and the ammonia from the cadaver, produced the image in front of us.

My husband was awed by my reasoning. He said he'd forgotten that I could be so smart and helpful. For several days, he endeavored to take care of me and to stay out of the bars. This made up for some of our misery and for being abandoned by the one-eyed woman who swore she'd seen the devil standing among the flames. She fled that same night and tried to convince me to go with her. Something told me it was my last chance to save myself, but another voice replied that it was my last chance to save my husband. He seemed changed. He was caring again and, when he looked at me, I saw something of the twinkle that used to come into his eyes when he caressed Plutón. I gave the maid the few dollars I could scrape together and off she went, crying for me as I cried for her.

For some time thereafter, my husband gave up drinking and hitting me. Something akin to remorse gnawed at him from inside. Perhaps it wasn't love he was showing me, but respect. A few weeks later, he went back to disappearing all night in his favorite slums. He'd come back drunk, but less so that before, or maybe he showed it less. He still wasn't hitting me, but he treated me with a 
coldness that was almost harder to take. I discovered that indifference can hurt more than fists. Someone who hits you sees you. Someone who doesn't even see you can't hit you.

But hope is the most perverse of human emotions and it kept right on growing in my womb, ashamed and powerful. I imagined that one day l'd wake up and our house wouldn't have burned down, the black cat wouldn't have been the one murdered, my husband would be who he once was.

And so, when he brought a black cat home with him one night, I thought that Plutón had actually come back from the dead. I picked it up in my arms and saw that it was missing an eye just like Plutón and my faithful maid, who I missed terribly. There were just two little differences. Plutón had been a tomcat, but this one was female. One her chest was a small white mark, and at first I couldn't tell what it was. In the following days, though, the mark grew clearer, its lines more precise. May God have mercy on my soul! It was an outline of the gallows where my husband had killed the black cat! Of the gallows that cast a shadow over every day of my life. Seeing my husband with this cat, I thought we were starting over. Now we had the chance to make up for our cruelty to that animal. This one was our chance to be good. If the black cat had come back from the dead, our house hadn't burned down, and our marriage would go back to being as loving and happy as the strange times would allow.

It was in this hope that I lavished on that cat all the pampering and care that my husband wouldn't let me give him. Letting yourself be loved is one way of giving. My husband denied it to me. He didn't raise his voice. He didn't even talk to me for days on end. My presence seemed to irritate him and yet, at times, he'd reach out and caress my hair, and that same, sad old hope would hunker down in my chest.

The cat was even more affectionate than Platón had been. I asked my husband where he'd found her and he said that Heaven or Hell had sent her to us. I ignored this. The animal followed me everywhere, pressing itself against me. Her affection was so strong that I actually began to get my appetite back, and I could be found talking to myself or laughing while I ironed the linens. I'd always hated chores when I had help to do them for me, but now they were my refuge from fear and idleness. The cat transformed all my little moments into games, rubbing up against me and 
curling up in my lap, leaping around happily and raising her tail like a question mark. Everything still seemed possible.

Even if my husband hadn't gone back to being good, he wasn't so bad now. If he wasn't loving, at least he wasn't evil. I know that his heart was gentle, that he was the man who had loved weak creatures and protected animals. He adored the black cat almost as much as I did. I encouraged her following him and showing her affection. I did much the same. In spite of our reduced circumstances, I did my best to look attractive for him. I arranged my ringlets against my décolletage and, since there was no money for things like make-up, I rubbed lavender on my underclothes. I cooked all his favorite dishes, which he ate mechanically, like he was chewing sand, and I never took offense. The little cat and I did everything we could to show him our love, because we thought that love was a contagious disease. Soon we'd learn that it's just a disease. My husband kept his distance from me and from the poor black cat. He eyed us with suspicion like he was worried we'd poison him. He avoided the animal and refused to look me in the eye. At night he'd toss and turn, slapping away my attempts at tenderness. It wasn't long before he started hitting me all over again. He turned those bloodshot eyes on me. It was like he could smile and, then next moment, go completely mad. When that happened, my only option was to try to run away. I never managed it without first getting my share of bruises. Every morning, a thousand tiny aches reminded me I was married to a monster. I resolved to do what I should have done so long before: leave him. I bundled up the few valuables I had left and hid them under the bed. I should have left that moment, but I wanted to take the cat with me. I couldn't stand the thought of my husband finding me gone and taking out his wrath on her. Besides, I didn't want to sneak off in the night like a thief. It was he who'd robbed me: robbed me of my time, my youth, my ability to enjoy life. He'd married a girl and turned her into an old lady. For months now, l'd turned all the mirrors in the house against the walls. The image they threw back tortured me. In the mirrors, my eyes were a smashed mosaic of red lines, broken blood vessels. It was the face of a ghost I didn't recognize. I made up my mind to talk to him on a foggy day, under skies that threatened rain. It might not have been the best day for starting a new life, but I couldn't wait any longer. I said that I had something to tell him. He grabbed me by the arm and insisted on taking me down to the basement of our wretched house on the pretext that he needed my help chopping firewood. The blade of the 
axe gleamed in the darkness, shone in a way that reflected my huge, sad eyes. I had a sudden premonition. The black cat followed me, winding herself around my legs like she was trying to stop me from going down those horrible stairs. My husband nearly tripped over her. This made him furious. He raised the axe and would have killed her right there if I hadn't stopped his arm. For a second I thought he might kill me too. I knew he wasn't capable, though, that he might be violent and difficult when the alcohol was controlling him, but he couldn't ever take the life of a poor, defenseless creature who had always answered evil with good. I looked into his eyes and saw they were full of tears, the same ones he'd cried when he hanged the tomcat. In the same moment, I felt the pain in my throat, and the hot liquid that splashed against my face. My last thought was about the little cat, the innocent creature that I, in my foolishness, had condemned to Hell.

In the darkness, I could hear the rhythmic sound of a pick and a shovel, and my husband's wheezing breath. I must have been badly hurt, but I didn't feel any pain. Was this death? I tried to move, but found I couldn't. I was deeply, deeply afraid. I heard sounds like a bricklayer meticulously building a wall. Maybe death is darkness and strange noises. I felt a comforting presence, purring and a brush of soft fur. Somehow the little black cat had found a way to accompany me into that darkness.

It was a long time before I realized that I had become the black cat. With my one good eye, I peered into the darkness. The missing one stung a bit. I saw what was left of my body, oozing with strange and terrible liquids. Then it was really true. I was dead. He had killed me. I should have left a long time ago, but somehow I still felt sorry for him. I pitied my murderer, blinded by his rage. I heard him cursing as he finished the wall he'd stashed us in, what was left of me and my guardian angel. He'd sealed us up in a basement wall, just like monks used to do with their victims in the Middle Ages. How it was l'd turned into the black cat seemed less mysterious than the fact that the sweet boy l'd known had turned into my killer. Appearances had deceived me. All appearances. That's why it doesn't seem so strange that l'd believed myself a woman in a bad marriage, but in reality I am an injured black cat waiting in the darkness.

I can close my eyes. I cannot close my ears. 
I hear voices. It's the police. I have to get their attention. But all I want to do is sleep. Sleep and forget. l've been here so long, l've forgotten daylight. The air in my tomb is moist and it erodes memories. I can't move. I don't want to move. Then I hear his laughter, fierce with triumph. He bangs the wall like he wants to wake me up from this eternal sleep.

You can close your eyes, but you can't close your ears.

I hear a cry. An inhuman cry. It can't be coming from me. A howl of fear and triumph. A funeral dirge, a child sobbing. All the tears I didn't shed, all the strength that wasn't there in time suddenly escapes from me now. It breaks down the wall and I see the terrified face of my killer, staring into the single eye of the cat who will stare back at him for all of the eternity l'll never get.

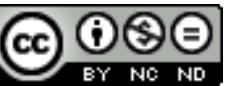

Creative Commons Attribution-NonCommercial-NoDerivatives 4.0 International License 